\title{
Response to treatment in Brazilian patients with chronic hepatitis $C$ is associated with a single-nucleotide polymorphism near the interleukin-28B gene
}

\author{
Tarciana Grandi ${ }^{1,2}$, Cláudia Maria Dornelles da Silva ${ }^{1,3,4}$, Karine Medeiros Amaral' \\ Paulo Dornelles Picon ${ }^{5}$, Cintia Costi ${ }^{1}$, Nicole Nascimento da Fré1, \\ Marilu Fiegenbaum ${ }^{6,7,8}$, Christian Niel ${ }^{9}$, Maria Lucia Rosa Rossetti ${ }^{1,2,4} /+$
}

\begin{abstract}
${ }^{1}$ Centro de Desenvolvimento Científico e Tecnológico, Fundação Estadual de Produção e Pesquisa em Saúde, Porto Alegre, RS, Brasil ${ }^{2}$ Programa de Pós-Graduação em Biologia Celular e Molecular, Universidade Federal do Rio Grande do Sul, Porto Alegre, RS, Brasil ${ }^{3}$ Programa de Pós-Graduação em Diagnóstico Genético e Molecular ${ }^{4}$ Programa de Pós-Graduação em Genética e Toxicologia Aplicada, Universidade Luterana do Brasil, Canoas, RS, Brasil ${ }^{5}$ Centro de Aplicação e Monitorização de Medicamentos Injetáveis, Porto Alegre, RS, Brasil ${ }^{6}$ Programa de Pós-Graduação em Patologia ${ }^{7}$ Programa de Pós-Graduação em Ciências da Saúde, Universidade Federal de Ciências da Saúde, Porto Alegre, RS, Brasil ${ }^{8}$ Programa de Pós-Graduação em Biociências e Reabilitação, Centro Universitário Metodista, Instituto Porto Alegre, Porto Alegre, RS, Brasil ' ${ }^{2}$ Laboratório de Virologia Molecular, Instituto Oswaldo Cruz-Fiocruz, Rio de Janeiro, RJ, Brasil
\end{abstract}

A single-nucleotide polymorphism (SNP) upstream of interleukin (IL)28B was recently identified as an important predictor of the outcome of chronic hepatitis C patients treated with pegylated interferon plus ribavirin (PEG-IFN/ $R B V)$. The aim of this study was to investigate the association between the IL28B gene polymorphism (rs12979860) and virological response in chronic hepatitis $C$ patients. Brazilian patients $(n=263)$ who were infected with hepatitis $C$ virus (HCV) genotype 1 and were receiving PEG-IFN/RBV were genotyped. Early virological response (EVR) (12 weeks), end-of-treatment response (EOTR) (48 weeks), sustained virological response (SVR) (72 weeks) and relapse were evaluated using conventional and quantitative polymerase chain reaction (PCR) assays. The frequency of the C allele in the population was $39 \%$. Overall, $43 \%$ of patients experienced SVR. The IL28B CC genotype was significantly associated with higher treatment response rates and a lower relapse rate compared to the other genotypes [84\% vs. 58\% EVR, 92\% vs. 63\% EOTR, 76\% vs. 38\% SVR and $17 \%$ vs. $40 \%$ relapse rate in CC vs. other genotypes (CT and TT), respectively]. Thus, the IL28B genotype appears to be a strong predictor of SVR following PEG-IFN/ $R B V$ therapy in treatment-naïve Brazilian patients infected with HCV genotype 1. This study, together with similar research examining other SNPs, should help to define adequate protocols for the treatment of patients infected with HCV genotype 1, especially those with a poor prognosis.

Key words: IL28B - HCV - virological response - treatment - Brazil

Hepatitis $\mathrm{C}$ virus (HCV) infection is a global health problem affecting an estimated 170 million people worldwide (WHO 2011). HCV infection is usually persistent and approximately $30 \%$ of individuals with persistent infection develop chronic liver diseases, including cirrhosis and hepatocellular carcinoma, after an asymptomatic period of several years (Chevaliez \& Pawlotsky 2007, Manzia et al. 2010). Patients with chronic hepatitis $\mathrm{C}$ are generally treated for 24-48 weeks with pegylated interferon (PEG-IFN) alpha $2 \mathrm{a}$ or $2 \mathrm{~b}$ in combination with ribavirin (RBV). This treatment is not only expensive, but is also associated with side effects that can result in reduced compliance and even treatment interruption. HCV clearance, or sustained virological response (SVR), is defined as a negative HCV RNA test 24 weeks after the cessation of therapy.

Financial support: FEPPS, FAPERGS (Edital 06/2010)

+ Corresponding author: mrossett@terra.com.br

Received 30 March 2012

Accepted 28 July 2012
A higher SVR rate has been observed in patients infected with HCV genotypes 2 and 3 compared to those infected with genotype 1 , which is the most common genotype found in Europe and the Americas (Manns et al. 2001, Fried et al. 2002, Campiotto et al. 2005, Silva et al. 2007, McHutchison et al. 2009). Furthermore, other host and viral factors, such as advanced liver fibrosis, advanced age and high baseline viral load (VL), have been associated with worse treatment outcomes (McHutchison et al. 2009). For this reason, decisions regarding the inclusion of certain individuals in treatment protocols with the current standard-of-care, i.e., IFN-based therapy, are complex and rely on a balanced assessment of host and viral characteristics (McCarthy et al. 2010, Mangia 2011).

Recently, genome-wide association studies (GWAS) have suggested that several highly correlated, common single-nucleotide polymorphisms (SNPs), which are located on a linkage disequilibrium block in the vicinity of three genes located on chromosome 19, interferon $\lambda 1$ [interleukin (IL)29], $\lambda 2$ (IL28A) and $\lambda 3$ (IL28B), are strongly associated with the response of patients infected with HCV genotype 1 to PEG-IFN/RBV therapy (Ge et al. 2009, Suppiah et al. 2009, Tanaka et al. 2009). Specifi- 
cally, SNP rs12979860, which is located three kilobases upstream of the $I L 28 B$ gene, is associated with a greater than two-fold difference in the proportion of patients who achieve SVR (Ge et al. 2009).

The aim of this study was to investigate whether the $I L 28 B$ gene polymorphism (rs12979860) and other variables could predict the outcome of antiviral therapy in a cohort of HCV genotype 1-infected, PEG-INF treatment-naïve Brazilian patients receiving PEG-IFN/ RBV therapy.

\section{PATIENTS, MATERIALS AND METHODS}

Patient characteristics - A prospective cohort study was carried out between September 2008-August 2009. The patients received free antiviral treatment at the Centre for Injectable Drug Administration and Monitoring (CAMMI) in Porto Alegre, state of Rio Grande do Sul. To receive free treatment, the patients had to meet the following conditions of the Brazilian Ministry of Health (Sander et al. 2002): (i) positive HCV RNA assays, (ii) transaminase [alanine aminotransferase (ALT) and aspartate aminotransferase] levels at least 1.5 times above the upper limit in at least three separate measurements, (iii) recent liver biopsy showing septal fibrosis (Metavir score of F2 or greater), (iv) between 18-70 years of age and (v) a platelet count $>75.000 / \mathrm{mm}^{3}$ (patients with cirrhosis) or $>90.000 / \mathrm{mm}^{3}$ (without cirrhosis) and neutrophil/granulocyte counts $>1.500 / \mathrm{mm}^{3}$. Treatment was initiated only after the determination of each patient's genotype and VL. A few patients failed to fulfil these conditions, but accessed free treatment following judicial decisions. To be enrolled in the study, patients had to be infected with HCV genotype 1 and be naïve to PEG-IFN therapy. Overall, 299 patients received the standard dose of PEG-IFN $2 \mathrm{a}$ or $2 \mathrm{~b}(180 \mu \mathrm{g}$ or $1.5 \mu \mathrm{g} / \mathrm{kg}$, respectively) plus RBV $(1.250 \mathrm{mg} /$ day for body weights $>75 \mathrm{~kg}$ or $1.000 \mathrm{mg} /$ day for body weights $\leq 75 \mathrm{~kg}$ ). The normal duration of antiviral therapy was 48 weeks. However, treatment was interrupted after 12 weeks for non-responders (see below). Furthermore, data analysis was not possible for 36 subjects because of death or the interruption of treatment due to severe side effects or other reasons. Therefore, the results from 263 patients were analysed. Demographic, biochemical and histological data were collected from the patients' clinical charts.

Written informed consent was obtained from each patient. The study protocol was conducted in accordance with the provisions of the ethical guidelines of the Declaration of Helsinki and the study was approved by the Research Ethics Committee of the Public Health School of Rio Grande do Sul, Brazil.

SNP analysis - The three possible IL28B genotypes (SNP rs12979860) were defined as CC, CT and TT. SNP genotyping was performed by direct sequencing after PCR amplification. The following PCR oligonucleotide primer sequences were designed using the National Center for Biotechnology Information DNA database: 5'-CGGAGGATCCCTCCTGGGGC-3' (sense) and 5'TTCCCACCACGAGACCCCCG-3' (antisense). The polymerase chain reaction (PCR) amplification mixture contained $5 \mu \mathrm{L}$ of genomic DNA extracted from blood,
20 pmol of each oligonucleotide, $200 \mathrm{mM}$ of deoxyribonucleoside triphosphates, $2 \mathrm{mM} \mathrm{MgSO}_{4}$, $1 \mathrm{x}$ high-fidelity PCR buffer (Invitrogen, Carlsbad, CA) and 0.25 U Platinum Taq DNA polymerase (Invitrogen) in a total reaction volume of $50 \mu \mathrm{L}$. The following cycling parameters were used for all reactions: one cycle of denaturation at $94^{\circ} \mathrm{C}$ for $5 \mathrm{~min}$ and 35 cycles of denaturation at $94^{\circ} \mathrm{C}$ for $30 \mathrm{~s}$, annealing at $65^{\circ} \mathrm{C}$ for $30 \mathrm{~s}$ and extension at $72^{\circ} \mathrm{C}$ for $45 \mathrm{~s}$. The final extension step was followed by 7-min incubation at $72^{\circ} \mathrm{C}$. The resulting 366-nt PCR product was sequenced in both directions using PCR primers, a Big Dye v1.1 kit (Applied Biosystems, Foster city, CA) and a 3130XL DNA sequencing system (Applied Biosystems). The electropherogram was visualised using Lasergene (DNAstar, Madison, WI) software.

Laboratory and histological tests - Null virological response (NVR) was defined as $<2 \log \mathrm{UI} / \mathrm{mL}$ reduction in HCV RNA at 12 weeks after the start of treatment (due to treatment interruption) or the presence of detectable HCV RNA by conventional PCR at the end of the course of therapy. Complete early virological response (cEVR) was defined as undetectable levels of HCV RNA at week 12. Partial EVR (pEVR) was defined as an HCV RNA reduction greater than $2 \log \mathrm{IU} / \mathrm{mL}$ at week 12 . End-oftreatment response (EOTR) was defined as the absence of detectable HCV RNA at the end of the course of treatment and SVR was defined as undetectable levels of HCV RNA 24 weeks after the completion of therapy (72 weeks after the initiation of treatment). Finally, relapse was defined as detectable HCV RNA levels during the followup evaluation of patients who had achieved EOTR.

The stage of liver fibrosis was scored according to the Metavir scoring system (F0-F4) and coded as a three-level variable (F0-F2, mild/moderate; F3-F4, severe; cirrhosis) for analysis. Serum HCV RNA quantitation results were classified as low $(<600.000 \mathrm{IU} / \mathrm{mL})$ or high ( $\geq 600.000 \mathrm{IU} / \mathrm{mL}$ ) VLs for analysis.

Statistical analysis - Allele frequencies were estimated by gene counting. Both deviation from Hardy-Weinberg equilibrium and comparisons between groups were assessed using the chi-squared test or Fisher's exact test with GraphPad InStat software version 2.04a (GraphPad Software, San Diego, CA). Quantitative variables between non-SVRs and SVRs were compared using the Student's $t$ test. Univariate logistic regression analyses were used to determine the predictors of treatment success. Age, gender, stage of liver fibrosis and VL were included into a multivariate logistic regression model to estimate adjusted odds ratios (ORs) and $95 \%$ confidence intervals (CIs). $\mathrm{p}$ values less than 0.05 were considered to be statistically significant. SPSS software v.16.0 (SPSS Inc, Chicago, IL) was used for these analyses.

\section{RESULTS}

Demographic, biochemical, virological and histological data and response to treatment - First, the patients were asked about possible modes of HCV infection. Blood transfusion (27.5\%), the use of illicit drugs (13.1\%), surgery (13.1\%) or a combination of these factors $(10.3 \%)$ were the most frequently cited routes. Tattoos, sexual transmis- 
sion and other modes of transmission were also reported. HCV-human immunodeficiency virus co-infection was mentioned in the clinical records of 57 patients. An analysis of the patient response to PEG-IFN/RBV treatment, according to their baseline characteristics, is shown in Table I. Overall, 114/263 (43.3\%) patients experienced SVR, whereas $149(56.7 \%)$ did not. The mean age of the patients was 50.4 years and 152/263 (58.6\%) individuals were male. No significant differences were observed with respect to gender, age or ALT levels between the SVR and non-SVR groups ( $p=0.257,0.435$ and 0.827 , respectively), although the mean age of the patients who achieved SVR was slightly lower. As expected, responders to PEG-IFN/ RBV treatment had a significantly lower VL $(p=0.001)$. Regarding the stage of liver fibrosis, no significant differences were found between the two groups coded as F0-F2 (mild/moderate) and F3-F4 (severe) $(\mathrm{p}=0.509)$. However, when comparing patients with cirrhosis to other patients, cirrhotic patients were less likely to respond $(\mathrm{p}=0.121)$.

IL28B genotype prevalence and baseline VLs - The frequencies of the various IL28B genotypes were in Har$\mathrm{dy}$-Weinberg equilibrium and the frequency of the $\mathrm{C}$ allele was $39 \%$. The IL28B genotypes were found to be CC, CT and TT in 38 (14.4\%), 128 (48.7\%) and 97 (36.9\%) patients, respectively. Patients with the IL28B CC genotype had a slightly lower mean VL at baseline in comparison to patients with a T allele $(6.20 \pm 0.99,6.39 \pm 0.74$ and 6.27 $\pm 0.74 \mathrm{log}$ IU/mL for patients with CC, CT and TT genotypes, respectively). However, when VL was categorised according to the threshold of $600.000 \mathrm{IU} / \mathrm{mL}$, the proportion of patients with a low baseline VL did not differ in relation to their IL28B genotype (data not shown).

Association between IL28B genotype and PEG-IFN/ $R B V$ response - Fig. 1 illustrates the association between the IL28B genotype and the percent of SVRs among
HCV genotype 1 patients receiving PEG-IFN/RBV treatment. The $\mathrm{C}$ allele was significantly associated with SVR status, particularly when two copies were present, with an OR of 5.31 as compared to non-CC (CT and TT) genotypes (95\% CI, 2.29-13.30; $\mathrm{p}<0.001)$.

As shown in Table II, the overall rates of cEVR and pEVR (measured at week 12 ) were $59 \%$ and $21 \%$, respectively (total $80 \%$ ). One hundred seventy-five out of 270 $(65 \%)$ patients reached EOTR after 48 weeks of treatment. However, among the subjects who initially achieved SVR with PEG-IFN/RBV therapy, 64 (35\%) relapsed.

Of the patients with the CC genotype, $84 \%$ achieved cEVR and $13 \%$ achieved pEVR. Thus, only one $(3 \%)$ patient did not achieve a two-log reduction in VL after 12 weeks of treatment. Greater than $90 \%$ of the patients showed a virological response at the end of the treatment period and $76 \%$ of the patients achieved SVR.

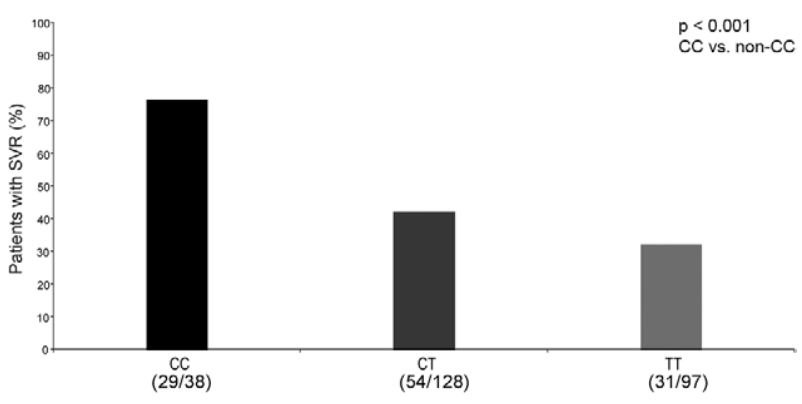

Fig. 1: association of interleukin-28B genotype with sustained virological response (SVR) in hepatitis C virus genotype 1 patients receiving pegylated interferon plus ribavirin treatment. For each genotype, the proportion of patients with SVR out of the total number of patients is shown.

\section{TABLE I}

Baseline characteristics of genotype 1 chronic hepatitis $\mathrm{C}$ patients treated with PEG-IFN/RBV and rate of sustained virological response

\begin{tabular}{|c|c|c|c|c|}
\hline Variable & $\begin{array}{c}\text { All } \\
(n=263)\end{array}$ & $\begin{array}{l}\text { Non-SVR } \\
(\mathrm{n}=149)\end{array}$ & $\begin{array}{c}\text { SVR } \\
(n=114)\end{array}$ & $\mathrm{p}$ \\
\hline Age (years) (mean \pm SD) & $50.4 \pm 10.7$ & $50.8 \pm 10.1$ & $48.9 \pm 11.5$ & $0.435^{a}$ \\
\hline Sex (male) $[\mathrm{n}(\%)]$ & $152(58.6)$ & $92(61.7)$ & $62(54.4)$ & $0.257^{b}$ \\
\hline ALT level (IU/L) (mean \pm SD) & $96.3 \pm 71.9$ & $97.2 \pm 70.8$ & $95.2 \pm 73.5$ & $0.827^{a}$ \\
\hline $\begin{array}{l}\text { Viral load }(\mathrm{IU} / \mathrm{mL})[\mathrm{n}(\%)] \\
\quad<600.000 \\
\geq 600.000\end{array}$ & $\begin{array}{c}56(21.8) \\
201(78.2)\end{array}$ & $\begin{array}{c}20(13.8) \\
125(86.2)\end{array}$ & $\begin{array}{l}36(32.1) \\
76(67.9)\end{array}$ & $\begin{array}{c}0.001^{b} \\
- \\
-\end{array}$ \\
\hline \multicolumn{5}{|l|}{ Metavir fibrosis stage [n (\%)] } \\
\hline $\mathrm{F} 0-\mathrm{F} 2$ & $146(60.1)$ & $80(58)$ & $66(62.9)$ & $0.509(\mathrm{~F} 0-\mathrm{F} 2 \text { vs. } \mathrm{F} 3-\mathrm{F} 4)^{b}$ \\
\hline F3-F4 & $97(39.9$ & $58(42)$ & $39(37.1)$ & - \\
\hline Cirrhosis & $41(16.9)$ & $28(20.3)$ & $13(12.4)$ & 0.121 (cirrhosis vs. others) $^{b}$ \\
\hline
\end{tabular}

$a$ : ANOVA; $b$ : Student's $t$ test; ALT: alanine aminotransferase; F0-F2 and F3-F4: Metavir score (mild/moderate and severe and cirrhosis, respectively); PEG-INF/RBV: pegylated interferon plus ribavirin (PEG-IFN/RBV); SD: standard deviation; SVR: sustained virological response. 
The IL28B CC genotype was associated with higher response rates to PEG-IFN/RBV treatment at all time points (12, 48 and 72 weeks). Moreover, in comparison to all other patients, the cEVR, EOTR and SVR rates were significantly higher for carriers of the CC genotype (all p-values $\leq 0.005$ ). Furthermore, relapse occurred at a lower frequency among CC patients. Statistically significant differences were not observed between $\mathrm{T}$ heterozygotes and homozygotes (all p-values $\geq 0.05$ ); however, the rate of SVR was higher among CT patients $(42 \%)$ compared to TT subjects (32\%) and the relapse rate was also lower in the former group ( $34 \%$ vs. $49 \%$ ).

Fig. 2 shows the proportion of CC and non-CC genotypes among patients who reached SVR, relapsed or were classified as non-responders. The frequency of the IL28B CC genotype in the relapse group was intermediate between the frequencies observed for the SVR and NVR groups. By univariate analysis, statistically significant differences were found between patients who reached SVR and who relapsed $(\mathrm{p}=0.01 ; \mathrm{OR}=3.3, \mathrm{CI}=$ 1.23-10.28), but not between those who relapsed or were classified as NVRs, which suggested that the IL28B CC genotype influenced SVR, but could not be used to accurately distinguish patients who relapse from those with NVR $(\mathrm{p}=0.173 ; \mathrm{OR}=2.83, \mathrm{CI}=0.57-18.50)$. As shown in Table III, after making adjustments for age, gender, stage of liver fibrosis and VL in the multivariate analysis, the difference between patients who reached SVR and who relapsed remained statistically significant $(\mathrm{p}=0.011 ; \mathrm{OR}=3.98, \mathrm{CI}=1.38-11.48)$.

\section{DISCUSSION}

Chronic hepatitis $\mathrm{C}$ has been recognised as a progressive fibrotic liver disease. However, little is known about the molecular and cellular mechanisms responsible for inter-individual heterogeneity in the virological response to PEG-IFN/RBV treatment among patients infected with HCV genotype 1. A better understanding of these mechanisms may facilitate the development of treatment strategies and could delay disease progression, especially for patients who fail to achieve SVR after undergoing current standard therapy.

The $I L 28 B$ gene encodes a protein also known as IFN lambda 3, which is thought to suppress the replication of various viruses, including HCV (Robek et al.

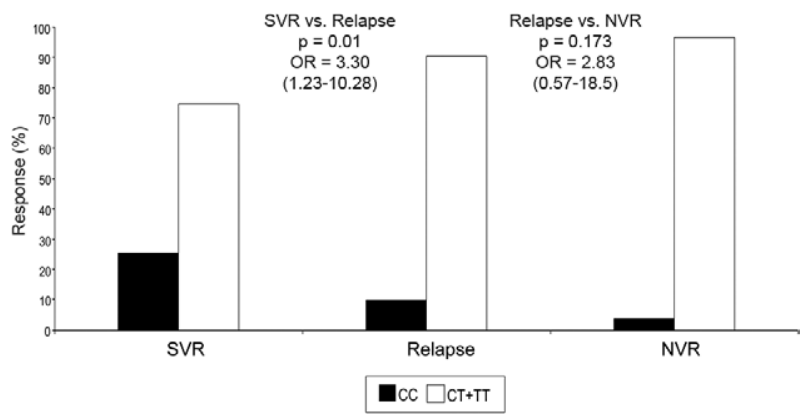

Fig. 2: association between interleukin (IL)28B genotype and threelevel treatment outcome in chronic hepatitis $\mathrm{C}$ virus patients. The rates of null virological response (NVR), relapse and sustained virological response (SVR) are shown. Odds ratios (OR) and 95\% confidence intervals are for IL28B CC vs. CT/TT genotypes, comparing SVR patients to relapsers and relapsers to NVR patients. The $p$ value shown is for the effect of the IL28B CC genotype in a univariate logistic regression analysis.

\section{TABLE III}

Association between interleukin-28B genotype and three-level treatment outcome with multivariate logistic regression adjusted for age, gender, viral load and stage of liver fibrosis

\begin{tabular}{lccc}
\hline Variable & OR & $95 \%$ CI & $\mathrm{p}$ \\
\hline SVR x relapse & & & \\
\hline Age (years) & 0.974 & $0.938-1.010$ & 0.155 \\
Sex (male) & 1.976 & $0.928-4.210$ & 0.077 \\
Viral load $<600.000 \mathrm{IU} / \mathrm{mL}$ & 0.291 & $0.115-0.735$ & 0.009 \\
Fibrosis & 1.343 & $0.620-2.905$ & 0.454 \\
IL28B CC genotype & 3.981 & $1.381-11.480$ & 0.011 \\
\hline
\end{tabular}

Relapse x NVR

\begin{tabular}{lccc}
\hline Age (years) & 1.031 & $0.99-1.073$ & 0.137 \\
Sex (male) & 0.842 & $0.385-1.840$ & 0.666 \\
Viral load $<600.000 \mathrm{IU} / \mathrm{mL}$ & 1.243 & $0.431-3.586$ & 0.687 \\
Fibrosis & 0.354 & $0.168-0.748$ & 0.007 \\
IL28B CC genotype & 2.531 & $0.531-12.062$ & 0.244 \\
\hline
\end{tabular}

CI: confidence interval; NVR: null virological response; OR: odds ratio; SVR: sustained virological response.

TABLE II

Rates of virological response and interleukin-28B genotypes

\begin{tabular}{lccccccc}
\hline $\begin{array}{l}\text { Treatment } \\
\text { response }\end{array}$ & $\begin{array}{c}\text { Overall } \\
\mathrm{n}(\%)\end{array}$ & $\begin{array}{c}\mathrm{CC} \\
\mathrm{n}(\%)\end{array}$ & $\begin{array}{c}\mathrm{CT} \\
\mathrm{n}(\%)\end{array}$ & $\begin{array}{c}\mathrm{TT} \\
\mathrm{n}(\%)\end{array}$ & $\begin{array}{c}\text { CC vs. CT } \\
\mathrm{p}\end{array}$ & $\begin{array}{c}\text { CC vs. TT } \\
\mathrm{p}\end{array}$ & $\begin{array}{c}\text { CT vs. TT } \\
\mathrm{p}\end{array}$ \\
\hline cEVR - week 12 & $158 / 269(59)$ & $32 / 38(84)$ & $76 / 132(58)$ & $58 / 99(59)$ & 0.002 & 0.005 & 0.894 \\
pEVR - week 12 & $58 / 269(21)$ & $5 / 38(13)$ & $30 / 132(23)$ & $25 / 99(25)$ & 0.257 & 0.167 & 0.755 \\
EOTR - week 48 & $175 / 270(65)$ & $36 / 39(92)$ & $83 / 130(64)$ & $64 / 101(63)$ & 0.001 & 0.001 & 1.000 \\
Relapse & $64 / 178(35)$ & $6 / 35(17)$ & $28 / 82(34)$ & $30 / 61(49)$ & 0.077 & 0.002 & 0.086 \\
SVR - week 72 & $114 / 263(43)$ & $29 / 38(76)$ & $54 / 128(42)$ & $31 / 97(32)$ & $<0.001$ & $<0.001$ & 0.128 \\
\hline
\end{tabular}

cEVR: complete early virological response; EOTR: end-of-treatment response; pEVR: partial EVR; SVR: sustained virological response. Comparisons between groups were assessed by Fisher's exact test. 
2005, Marcello et al. 2006). A polymorphism near the IL28B gene on chromosome 19, rs12979860, has recently been described as a determining factor in the response to treatment, as individuals with the CC genotype carry a more favourable prognosis than those with the CT or TT genotypes. At this genomic position, the frequency of the $\mathrm{C}$ allele may vary depending on geographical region and ethnicity (Thomas et al. 2009). The Brazilian genetic structure is considered to be quite complex and is one of the most heterogeneous in the world due to the ethnic admixture of people classified as European-derived, African-derived, Brazilian mulattos and Asian-derived, according to their reported ethnicity (IBGE 2000, 2008). The current study was the first to investigate a large number of Brazilian patients and the frequency of the $\mathrm{C}$ allele was assessed in a cohort of 263 patients with liver fibrosis due to infection with $\mathrm{HCV}$ genotype 1. The $\mathrm{C}$ allele was present in $39 \%$ of patients, which is lower than the frequencies reported from Europe, Asia and Oceania, but similar to that observed in Africa (IBGE 2000, Thomas et al. 2009, Lin et al. 2011), and this finding may be due to the large proportion of African descendants in the Brazilian population.

The present study confirmed that the IL28B polymorphism is a good predictor of SVR, independent of other factors, such as age, gender, stage of liver fibrosis and VL. Due to the admixture of the Brazilian population over time, it is not possible to classify Brazilian individuals into ethnic groups, at least those based on skin colour (Pena et al. 2009). For this reason, it was not possible to exclude ethnicity as a confounding factor. Indeed, SNP rs12979860 was strongly associated with the response to standard-of-care PEG-IFN/RBV therapy, as demonstrated by higher virological response rates at weeks 12, 48 and 72 and lower rates of post-treatment relapse compared to other genotypes. The findings demonstrated in the current study are consistent with previous reports showing that PEG-IFN/RBV therapy is more effective at blocking the production of $\mathrm{HCV}$ in patients with the IL28B CC genotype and that the rate of viral decline is increased in patients with the CC compared to the CT or TT genotypes, which correlates with higher rates of SVR (Thompson et al. 2010, Lindh et al. 2011, Stättermayer et al. 2011). Here, the SVR rate was $76 \%$ for patients with the CC genotype and 38\% for those with the CT or TT genotypes. Regardless, the SVR rate for non-CC patients was higher than the rates previously reported for Caucasian (23\%), African-American (9\%) and European (28\%) patients (Rauch et al. 2010).

Because we focused on a unique SNP, the impact of the present study may be limited. However, these findings, together with the results of GWAS (Ge et al. 2009, Suppiah et al. 2009, Tanaka et al. 2009), provide a rationale for the development of prognostic tests and customised IFN-based therapies for patients with chronic hepatitis C. Well-adapted therapies should be based on the baseline characteristics of the patient and should follow a responseguided approach. According to our data, the presence of the IL28B CC genotype may indicate a high probability of achieving SVR. In contrast, patients with non-CC geno- types and those with other predictors of poor response, such as advanced fibrosis or high VL, would be unlikely to achieve SVR. Along with previous reports, our results may be used to decide whether to implement a PEG-IFN/ RBV treatment regimen or to wait for more effective therapeutic protocols, such as those currently in development that are based on HCV protease and polymerase inhibitors (Jacobson et al. 2011, Poordad et al. 2011).

In conclusion, the IL28B genotype appears to be the strongest predictor of SVR following PEG-IFN plus RBV therapy in treatment-naïve patients infected with $\mathrm{HCV}$ genotype 1. Recently, important genetic findings related to the antiviral response in patients with chronic hepatitis C suggest that customised therapy is likely to be implemented in the near future. Further clinical trials are needed to determine whether HCV genotype 1-infected patients with the favourable IL28B CC genotype could be treated for a shorter duration with equal clinical benefit, which would reduce the cost of long-term treatment and the burden of adverse side effects.

\section{ACKNOWLEDGEMENTS}

To CAMMI staff, for their kind secretarial support, and to all patients, for their participation in this study.

\section{REFERENCES}

Campiotto S, Pinho JR, Carrilho FJ, da Silva LC, Souto FJ, Spinelli V, Pereira LM, Coelho HS, Silva AO, Fonseca JC, Rosa H, Lacet CM, Bernardini AP 2005. Geographic distribution of hepatitis C virus genotypes in Brazil. Braz J Med Biol Res 38: 41-49.

Chevaliez S, Pawlotsky JM 2007. Hepatitis C virus: virology, diagnosis and management of antiviral therapy. World J Gastroenterol 13: 2461-2466.

Fried MW, Shiffman ML, Reddy KR, Smith C, Marinos G, Gonçales FL Jr, Häussinger D, Diago M, Carosi G, Dhumeaux D, Craxi A, Lin A, Hoffman J, Yu J 2002. Peginterferon alpha-2a plus ribavirin for chronic hepatitis C virus infection. N Engl J Med 347: 975-982.

Ge D, Fellay J, Thompson AJ, Simon JS, Shianna KV, Urban TJ, Heinzen EL, Qiu P, Bertelsen AH, Muir AJ, Sulkowski M, McHutchison JG, Goldstein DB 2009. Genetic variation in IL28B predicts hepatitis C treatment-induced viral clearance. Nature 461: 399-401.

IBGE - Instituto Brasileiro de Geografia Estatística 2000. Brasil 500 anos de povoamento, Rio de Janeiro. Available from: ibge.gov. $\mathrm{br} / \mathrm{brasil} 500 /$

IBGE - Instituto Brasileiro de Geografia Estatística 2008. Características étnico-raciais da população - um estudo das categorias de classificação de cor ou raça. Available from:ibge.gov.br/home/estatistica/populacao/caracteristicas_raciais/default_raciais.shtm.

Jacobson IM, McHutchison JG, Dusheiko G, Di Bisceglie AM, Reddy KR, Bzowej NH, Marcellin P, Muir AJ, Ferenci P, Flisiak R, George J, Rizzetto M, Shouval D, Sola R, Terg RA, Yoshida EM, Adda N, Bengtsson L, Sankoh AJ, Kieffer TL, George S, Kauffman RS, Zeuzem S, Advance Study Team 2011. Telaprevir for previously untreated chronic hepatitis C virus. N Engl J Med 364: 2405-2416.

Lin CY, Chen JY, Lin TN, Jeng WJ, Huang CH, Huang CW, Chang SW, Sheen IS 2011. IL28B SNP rs12979860 is a critical predictor for on-treatment and sustained virologic response in patients with hepatitis C virus genotype-1 infection. PLoS ONE 6: e18322.

Lindh M, Lagging M, Arnholm B, Eilard A, Nilsson S, Norkrans G, Söderholm J, Wahlberg T, Wejstål R, Westin J, Hellstrand K 2011. 
IL28B polymorphisms determine early viral kinetics and treatment outcome in patients receiving peginterferon/ribavirin for chronic hepatitis C genotype 1. J Viral Hepat 18: 325-331.

Mangia A 2011. IL28B: a new wager in the skyline of hepatitis C virus infection. Dig Liver Dis 43: 177-179.

Manns MP, McHutchison JG, Gordon SC, Rustgi VK, Shiffman M, Reindollar R, Goodman ZD, Koury K, Ling M, Albrecht JK 2001. Peginterferon alpha-2b plus ribavirin compared with interferon alpha-2b plus ribavirin for initial treatment of chronic hepatitis C: a randomized trial. Lancet 358: 958-965.

Manzia TM, Di Paolo D, Sforza D, Toti L, Angelico R, Brega A, Angelico M, Tisone G 2010. Liver transplantation for hepatitis B and C virus-related cirrhosis: mid-term results. Transplant Proc 42: $1200-1203$.

Marcello T, Grakoui A, Barba-Spaeth G, Machlin ES, Kotenko SV, MacDonald MR, Rice CM 2006. Interferons alpha and lambda inhibit hepatitis $\mathrm{C}$ virus replication with distinct signal transduction and gene regulation kinetics. Gastroenterology 131: 1887-1898.

McCarthy JJ, Li JH, Thompson A, Suchindran S, Lao XQ, Patel K, Tillmann HL, Muir AJ, McHutchison JG 2010. Replicated association between an $I L 28 B$ gene variant and a sustained response to pegylated interferon and ribavirin. Gastroenterology 138: 2307-2314.

McHutchison JG, Lawitz EJ, Shiffman ML, Muir AJ, Galler GW, McCone J, Nyberg LM, Lee WM, Ghalib RH, Schiff ER, Galati JS, Bacon BR, Davis MN, Mukhopadhyay P, Koury K, Noviello S, Pedicone LD, Brass CA, Albrecht JK, Sulkowski MS, Ideal Study Team 2009. Peginterferon alfa-2b or alfa-2a with ribavirin for treatment of hepatitis C infection. $N$ Engl J Med 361: 580-593.

Pena SD, Bastos-Rodrigues L, Pimenta JR, Bydlowski SP 2009. DNA tests probe the genomic ancestry of Brazilians. Braz J Med Biol Res 42: 870-876.

Poordad F, McCone J Jr, Bacon BR, Bruno S, Manns MP, Sulkowski MS, Jacobson IM, Reddy KR, Goodman ZD, Boparai N, DiNubile MJ, Sniukiene V, Brass CA, Albrecht JK, Bronowicki JP, Sprint-2 Investigators 2011. Boceprevir for untreated chronic HCV genotype 1 infection. N Engl J Med 364: 1195-1206.

Rauch A, Kutalik Z, Descombes P, Cai T, Di Iulio J, Mueller T, Bochud M, Battegay M, Bernasconi E, Borovicka J, Colombo S, Cerny A, Dufour JF, Furrer H, Günthard HF, Heim M, Hirschel B, Malinverni R, Moradpour D, Müllhaupt B, Witteck A, Beckmann JS, Berg T, Bergmann S, Negro F, Telenti A, Bochud PY, Swiss Hepatitis C Cohort Study, Swiss HIV Cohort Study 2010. Genetic variation in IL28B is associated with chronic hepatitis C and treatment failure: a genome-wide association study. Gastroenterology 138: 1338-1345.
Robek MD, Boyd BS, Chisari FV 2005. Lambda interferon inhibits hepatitis B and C virus replication. J Virol 79: 3851-3854.

Sander GB, Kuchenbecker RS, Amaral KM, Krug BC 2002. Hepatite viral crônica C. In A Beltrame (ed.), Protocolos clínicos e diretrizes terapêuticas - medicamentos excepcionais, Gráfica Pallotti, Porto Alegre, p. 431-454.

Silva CMD, Costi C, Krug LP, Ramos AB, Grandi T, Gandolfi VL, Menezes ME, Ocampos M, Niel C, Rossetti MLR 2007. High proportion of hepatitis $\mathrm{C}$ virus genotypes 1 and 3 in a large cohort of patients from Southern Brazil. Mem Inst Oswaldo Cruz 102: $867-870$.

Stättermayer AF, Stauber R, Hofer H, Rutter K, Beinhardt S, Scherzer TM, Zinober K, Datz C, Maieron A, Dulic-Lakovic E, Kessler HH, Steindl-Munda P, Strasser M, Krall C, Ferenci P 2011. Impact of IL28B genotype on the early and sustained virologic response in treatment-naive patients with chronic hepatitis C. Clin Gastroenterol Hepatol 9: 344-350.

Suppiah V, Moldovan M, Ahlenstiel G, Berg T, Weltman M, Abate ML, Bassendine M, Spengler U, Dore GJ, Powell E, Riordan S, Sheridan D, Smedile A, Fragomeli V, Müller T, Bahlo M, Stewart GJ, Booth DR, George J 2009. IL28B is associated with response to chronic hepatitis $\mathrm{C}$ interferon-alpha and ribavirin therapy. Nat Genet 41: 1100-1104.

Tanaka Y, Nishida N, Sugiyama M, Kurosaki M, Matsuura K, Sakamoto N, Nakagawa M, Korenaga M, Hino K, Hige S, Ito Y, Mita E, Tanaka E, Mochida S, Murawaki Y, Honda M, Sakai A, Hiasa Y, Nishiguchi S, Koike A, Sakaida I, Imamura M, Ito K, Yano K, Masaki N, Sugauchi F, Izumi N, Tokunaga K, Mizokami M 2009. Genome-wide association of IL28B with response to pegylated interferon-alpha and ribavirin therapy for chronic hepatitis $\mathrm{C}$. Nat Genet 41: 1105-1109.

Thomas DL, Thio CL, Martin MP, Qi Y, Ge D, O'Huigin C, Kidd J, Kidd K, Khakoo SI, Alexander G, Goedert JJ, Kirk GD, Donfield SM, Rosen HR, Tobler LH, Busch MP, McHutchison JG, Goldstein DB, Carrington M 2009. Genetic variation in IL28B and spontaneous clearance of hepatitis C virus. Nature 461: 798-801.

Thompson AJ, Muir AJ, Sulkowski MS, Ge D, Fellay J, Shianna KV, Urban T, Afdhal NH, Jacobson IM, Esteban R, Poordad F, Lawitz EJ, McCone J, Shiffman ML, Galler GW, Lee WM, Reindollar R, King JW, Kwo PY, Ghalib RH, Freilich B, Nyberg LM, Zeuzem S, Poynard T, Vock DM, Pieper KS, Patel K, Tillmann HL, Noviello S, Koury K, Pedicone LD, Brass CA, Albrecht JK, Goldstein DB, McHutchison JG 2010. Interleukin-28B polymorphism improves viral kinetics and is the strongest pretreatment predictor of sustained virologic response in genotype 1 hepatitis C virus. Gastroenterology 139: 120-129.

WHO - World Health Organization 2011. Hepatitis C. Available from: who.int/mediacentre/factsheets/fs164/en/. 